\title{
Applicability of the circular economy paradigm-the case of Andhra Pradesh, India
}

\author{
Keywords: Andhra Pradesh, circular economy, forestry, India
}

JEL: Q32, Q38

\section{Introduction}

Our economy is inherently linear, and it is generally assumed that societal welfare can be increased through the mass production of more and more goods from materials derived from our planet's resources. The goods are used, discarded, and this cycle is repeated which is leading to exponential decrease of earth's resources. The central proposition of this paper is that a Circular Economy (CE), where products and materials are not destroyed at the end of their useful life, but are utilized to make new and different products over and over again, must gradually replace the traditional, linear economic model. While the philosophical and moral aptness underlying the principles of the CE has global acceptance, its implementation does seem to spew fresh challenges to policy makers, especially in resource constrained economies like India. Finland is in the forefront of redesigning its traditional, linear economy into a CE through innovative business models in its forestry, food production, and transportation sectors. In the CE paradigm, the management of the forestry and environment sector is important as they are vital sources of tangible and exhaustible resources like timber, fossil fuels, minerals and metals, and watersheds. Healthy forests also resonate with lesser pollution and imply a better quality of life. The paper identifies some strength in the Finnish forestry sector which is facilitating the quick transition to the CE through innovative business models. ${ }^{1}$ One, 75 percent of the state's forests is private owned, with the average size of holding at around 30 hectares. This ownership pattern ensures quick adoption of best practices and commercial competencies of the private sector in sustainable forest management. Affirmative Government actions, subsidies support, and tax structure, encourage forest owners to use efficient silvicultural practices in forest management which align with the commercial incentives of timber procurement organizations, transportation companies, and forest machinery entrepreneurs towards forest conservation.

Two, gaming licenses, especially with reference to elk, and sale of forest recreation services are substantial revenue sources to forest owners, both public and private. Three, Finland emphasizes recycling, efficient use of natural resources, and renewable energy solutions in agro-forestry businesses (for example, the paper industry) which increases product life cycles, reduce depletion of resources, and encourages sharing to reduce costs. Can Finland's business processes, models, and approach to transition to the CE model be applicable to the forestry and agro-forestry business ecosystems in Andhra Pradesh (AP) state, India? In seeking some answers to this question, this article outlines some constraints in the Indian context. All forests are state-owned in AP (as elsewhere in India), which somewhat inhibits the participation of private sector in the forestry sector. Second, by virtue of its ownership, the State has not actively promoted the growth of forest-based industries. The existing wood-based industry saw mills, and forest-based medicine industry is subject to innumerable
Volume 8 Issue 5 - 2018

\author{
Sundar Balakrishna \\ Indian Forest Service, Director of Electronics Services Delivery \\ and Chief Executive Officer, Andhra Pradesh Information \\ Technology Academy, India
}

Correspondence: Sundar Balakrishna, Indian Forest Service, Director of Electronics Services Delivery and Chief Executive Officer, Andhra Pradesh Information Technology Academy, Government of Andhra Pradesh,Vijayawada, and Visiting Faculty (Economics area) in Indian Institutes of Management Indore, and Trichy.Tel, 918332959789, Email sundarb@iima.ac.in

Received: February 04, 2018 | Published: October 05, 2018

controls by the State. ${ }^{2}$ Third, a sizeable section of the population at the Bottom of the Pyramid, the forest-dependent communities, rely on forests for habitation, food, and fodder. This paper summarizes a study undertaken in Krishna district of AP where the future capital city (Amaravathi) of the newly formed AP state is planned. With 7 percent of the geographical area covered by dry deciduous, thorn, tropical evergreen scrub, and tidal swamp mangrove forests, Krishna district is representative of other districts in AP due to its mix of scrub, thorn, and evergreen forests. This study benefitted from consultations and interviews from a wide range of stakeholders in Krishna district which include senior officers in the environment and forest department (and allied ministries like agriculture, horticulture, water resources, industries, transportation, waste management, municipal corporation, and irrigation), middle level public representatives, business leaders, owners of forest-based businesses like saw mill owners, wood depots, nursery plantation owners, and fertilizers, and agro-forestry business consultants. The study identifies some opportunities in allied industrial sectors like agro-forestry, alternative medicines, transportation, and waste management in AP which can potentially facilitate the transition to a CE. The State's proactive policies in certain other sectors like Information Technology (IT) and rural lighting infrastructure forebode an encouraging transition towards the CE paradigm. So is the recent initiative of AP to encourage non cash transactions in the economy. However, these isolated opportunities and piecemeal nudges to reduce energy consumption and lengthen product life may be insufficient. The study finds a general lack of awareness of the CE concept in policy making circles in the AP Government which is a nontrivial dampener in attaining the CE objective.

To address this major block, the paper outlines several measures and channels to sensitize policy makers on the costs and benefits of the CE. It is also imperative that Government officials at all levels of hierarchy, the private sector, the not-for-profit sector, and the student population be exposed to the potential benefits of $\mathrm{CE}$, as several CE practices, especially with reference to decisions to buy or discard electronic appliances, lighting, and waste management, have roots in domestic lifestyles. ${ }^{3}$ A Government determined to transition 
toward the CE would craft policies, and promote process and business models to achieve the CE goal, and require an enlightened citizenry's cooperation in reaching this goal. The study notes with concern that the general levels of resource usage in AP is not accounted for in the state budget documents. Cost savings from using products longer and through recycling is substantial, while the reduced potential to create more jobs due to dip in demand for manufactured goods in a CE, relative to the linear economy may not be politically attractive. This may somewhat be counter balanced as a CE based on recycling, reuse, and extended product cycle is more labor intensive as compared to the traditional, linear economy where most processes are automated. The study also analyzes taxation as an instrument to achieve a CE. Goods made from secondary materials, and goods that are being reused must be exempt from the goods and sales tax (GST) as this tax has been paid during the initial manufacturing process. Ideally, it must be more expensive to use virgin materials to manufacture goods as compared to using recycled materials. The lessons from this study, and the documented best practices, may be of some interest to other states within India, and other similarly placed developing economies.

\section{Acknowledgements}

None.

\section{Conflict of interest}

The authors declared there is no conflict of interest.

\section{References}

1. Andhra Pradesh Forest Department \& Forests Report. Department of Environment, Forests, Science and Technology. Government of Andhra Pradesh, 2014.

2. Finnish Forest Research Institute. State of Finland's Forests 2015, Ministry of Agriculture and Forestry publication. 2015.

3. Sundar B. Joint Forest Management in India-an Assessment. International Forestry Review. 2017;19(4):495-511. 